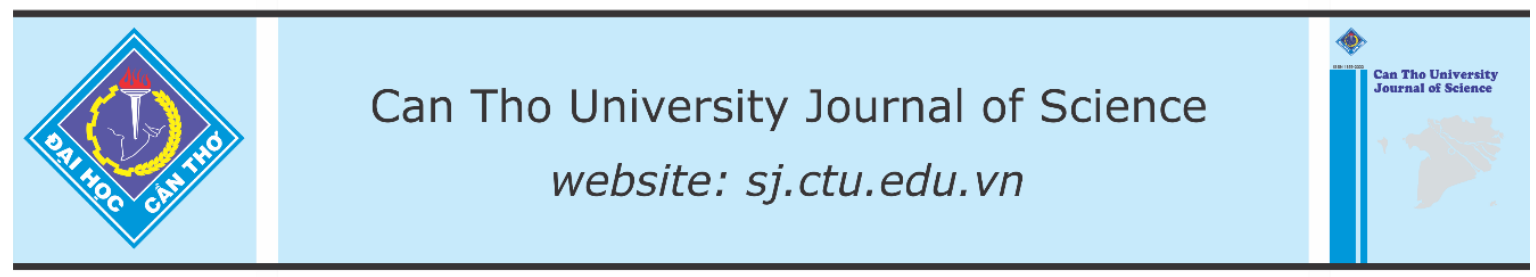

DOI: 10.22144/ctu.jen.2021.023

\title{
In vitro antibacterial activity of several plant extracts against fish bacterial pathogens
}

\author{
Tran Thi My Duyen ${ }^{1 *}$, Nguyen Trong Tuan ${ }^{2}$ and Tran Thi Tuyet Hoa ${ }^{1}$ \\ ${ }^{I}$ College of Aquaculture and Fisheries, Can Tho University, Viet Nam \\ ${ }^{2}$ College of Natural Sciences, Can Tho University, Viet Nam \\ *Correspondence: Tran Thi My Duyen (email: ttmduyen@ctu.edu.vn)
}

\section{Article info.}

Received 22 Feb 2021

Revised 12 Apr 2021

Accepted 04 Jun 2021

\section{Keywords}

Aeromonas hydrophila, antibacterial activity, Edwardsiella ictaluri, plant extract, Streptococcus agalactiae, zone of inhibition

\begin{abstract}
Crude methanol extract of 9 Vietnamese plants were in vitro screened for their antibacterial activity against three common freshwater fish pathogens including Aeromonas hydrophila, Edwardsiella ictaluri, and Streptococcus agalactiae. Agar disc diffusion method was used to evaluate the antibacterial activity, then solvent extract was performed for the extracts which exhibited the strongest and a broad-spectrum antibacterial activity. Minimal inhibitory concentration (MIC) was conducted for effective plant extracts using broth dilution method. The results indicated that most of the plant extracts exhibited antibacterial propeties to at least one tested bacterium. Headache tree (Premna corymbosa), bushwillows (Combretum quadrangulare) and Celandine spider flower (Cleome chelidonii) showed a broad-spectrum antibacterial activity. The largest inhibitory zones of $35 \mathrm{~mm}$ and $21 \mathrm{~mm}$ were observed for the extract of Premna corymbosa against $E$. ictaluri and $S$. agalactiae, respectively. E. ictaluri was found to be the most susceptible for all of the extracts while A. hydrophila was the most resistant. The MIC of effective plant extracts against tested bacteria ranged between $0.39 \mathrm{mg} / \mathrm{mL}$ and $3.125 \mathrm{mg} / \mathrm{mL}$. The result can be considered for further investigation of the development of an alternative therapy against bacterial infection in aquaculture.
\end{abstract}

\section{INTRODUCTION}

Bacterial diseases continue to be a severe constraint to sustainable aquaculture industry due to its high mortality level and heavy economic losses (Mishra et al., 2018). Amongst the common freshwater fish pathogens, Edwardsiella ictaluri and Aeromonas hydrophila were documented as the main cause of high mortality in striped catfish (Pangasianodon hypophthalmus) (Tu, Nguyen, et al., 2008). Moreover, Streptococcus agalactiae infection in tilapia outbreaks have been reported in many Asian countries, leading to $90 \%$ of mortality rate (Ha et al., 2011). Control and treatment of bacterial infection commonly relies on the use of chemical agents, particularly antibiotics to aquaculture ponds (Rico et al., 2013). However, the improper use of antibiotics is the main reason leading to the emerge and selection of antibiotic resistant-bacteria (Quach et al., 2014; Tu, Haesebrouck, et al., 2008). These resistant-bacteria or its genes, can be easily transferred to human via food consumption, via direct contact or via environment (Evans et al., 2009; Sreedharan et al., 2012). Thus, development of reliable alternative therapies against bacterial pathogens is crucial for improving both quality and quantity in aquaculture production.

Plant extracts have been chosen as a promising alternative to antibiotics due to its antibacterial 
properties and ability to promote growth, stimulate the immune system against bacterial infection (Bulfon et al., 2015; Ngo, 2015). Researchers have reported the antibacterial activity of many plants from different regions in the world. Turker et al. (2009) investigated antibacterial activity of aqueous, ethanol and methanol extracts obtained from 22 Turkish medicinal plants against fish pathogens and found that various solvent of Nuphar lutea, Nymphaea alba, Stachys annua, Genista lydia, Vinca minor, Fragaria vesca, Filipendula ulmaria, Helichrysum plicatum extracts revealed the highest inhibitory activity. In addition, the methanol extract of $V$. minor and the ethanol and aqueous extract of $N$. lutea showed a broad-spectrum antibacterial activity which against all of the tested bacteria including $A$. hydrophila, Yersinia ruckeri, Lactococcus garvieae, S. agalactiae and Enterococcus faecalis. In another study, various solvents extracts of 9 edible herbs as Table 1. Plants used in the study black pepper, clove, curry leaf, onion and Vietnamese coriander exhibited antibacterial activity against 9 common pathogenic bacteria in fish (Najiah et al., 2011). Furthermore, a number of studies indicate that some plants with antibacterial activity can be used as an alternative agent against bacterial infections in aquaculture (AftabUddin et al., 2017; Mohammed \& Arias, 2016; Zilberg et al., 2010).

Considering the huge potential of diversity plants as a source for antibacterial drugs, the present study aims to investigate the in vitro antibacterial activity of nine Vietnamese plant extracts (Table 1) against three common pathogenic bacteria including $A$. hydrophila, E. ictaluri and S. agalactiae, with the view of providing preliminary information about the antibacterial activity of local plants and its potential application in freshwater aquaculture.

\begin{tabular}{clllll}
\hline No. & Plant name & Family & Common name & Local name & Collection place \\
\hline 1 & Azadirachta indica & Meliaceae & Neem & Sầu đâu & An Giang \\
2 & Cayratia trifolia & Vitaceae & Fox grape & Dây vác & Hau Giang \\
3 & Cleome chelidonii & Cleomaceae & Celandine spider flower & Mần ri & Hau Giang \\
4 & Combretum quadrangulare & Combretaceae & Bushwilows & Trâm bầu & Hau Giang \\
5 & Cynara scolymus & Asteraceae & Artichoke & Atiso & Da Lat \\
6 & Kalanchoe pinnata & Crassulaceae & Air plant & Sống đời & Can Tho \\
7 & Premna corymbosa & Lamiaceae & Headache tree & Lá cách & Can Tho \\
8 & Wedelia chinensis & Asteraceae & Chinese wedelia & Cúc sài đất & Can Tho \\
9 & Xanthium strumarium & Asteraceae & Cocklebur & Ké đầu ngựa & Hau Giang \\
\hline
\end{tabular}

\section{METHODOLOGY}

\subsection{Preparation of plant extracts}

Fresh plants were collected from some areas in the Mekong Delta, Vietnam. All collected plants were washed through tap water and oven dried at $45^{\circ} \mathrm{C}$. After drying, dried plants were finely powdered. Subsequently, $100 \mathrm{~g}$ of plant powder were macerated 5 times in $1 \mathrm{~L}$ of methanol, each time for 24 hours at room temperature. The extracts were then filtered through Whatman filter paper and were evaporated in a rotary evaporator for obtaining crude methanol extracts. Based on the screening result of crude methanol extract, the extracts which demonstrate strong and broad spectrum inhibitory effect were selected for solvent extraction. The crude methanol extract was well-mixed with water followed by shaking with hexane and ethyl acetate to give a methanol-water extract, hexane extract and ethyl acetate extract, respectively (Nguyen Kim Phi Phung, 2007).

\subsection{Preparation of paper discs}

The plant extracts were dissolved in DMSO (VWR Prolabo, USA), then impregnated onto a paper disc (8 mm, Advantec, Tokyo, Japan) and air-dried in a sterilized flow cabinet for $30 \mathrm{~min}$. The positive controls were Doxycycline $(30 \mu \mathrm{g})$, Flofenicol $(30 \mu \mathrm{g})$ and Ampicillin $(10 \mu \mathrm{g})$ for A. hydrophila, E. ictaluri and $S$. agalactiae, respectively. Paper discs impregnated with DMSO were used as negative control.

\subsection{Preparation of bacterial inoculum}

Three isolates of fish pathogenic bacteria including A. hydrophila, E. ictaluri and S. agalactiae, provided by the Department of Aquatic Pathology, Can Tho University, were recovered on Tryptone Soya Agar (Himedia, India) plates and incubated at $28^{\circ} \mathrm{C}$ for 16-36 hours. Direct suspension method was used by picking some colonies then suspended in sterilized sodium solution $(0.85 \% \mathrm{NaCl})$. Afterward, the bacterial inoculum was adjusted to a concentration of $10^{8} \mathrm{CFU} / \mathrm{mL}$ by measuring the optical density through a spectrophotometer $\left(\mathrm{OD}_{610}=1\right.$ for $E$. 
ictaluri and $\mathrm{OD}_{610}=0.8-0.9$ for $A$. hydrophila and $S$. agalactiae).

\subsection{Determination of antibacterial activity}

Agar disc diffusion method was used to screen antibacterial activity of the plant extracts (Oonmetta-aree et al., 2006). The bacterial inocula were spread on Mueller Hinton Agar (Himedia, India) and kept for about $15 \mathrm{~min}$ in a flow cabinet to allow the surface of agar plate to dry. The prepared paper discs were placed onto MHA plates inoculated with respected bacteria, followed by incubation at $28^{\circ} \mathrm{C}$ for $16-48$ hours. The antibacterial activity of plant extracts was determined by measuring the diameter of inhibitory zone forming around the paper discs. All of experiments were performed in triplicate and the inhibitory zone's diameter of each plant extract is calculated as mean \pm standard deviation (SD). Describe the positive and negative controls.

\subsection{Determination of minimum inhibitory concentration (MIC)}

The plant extracts which showed inhibition $\geq 15 \mathrm{~mm}$ were selected to determine the minimum inhibitory concentration (MIC) using the broth dilution method (Oonmetta-aree et al., 2006). Briefly, a series of concentrations of plant extract was prepared by two-fold serial dilution, ranged from 0.024 to 25 $\mathrm{mg} / \mathrm{mL}$. Tubes containing $1 \mathrm{~mL}$ broth were inoculated with broth medium in the absence of bacteria (blank control sample), bacteria with medium (positive control sample), and bacteria with respective antibiotic (negative control samples). A. hydrophila and E. ictaluri were grown in Nutrient Broth (Difco, USA) while $S$. agalactiae was grown in Brain Heart Infusion Broth (Merck, Germany). The test tubes were incubated at $28^{\circ} \mathrm{C}$ for $16-48$ hours with gentle shaking. The MIC of the plant extracts was determined as the lowest concentration of plant extract where no bacterial growth by eyes. The MIC experiment was performed in triplicate.

\subsection{Data analysis}

Mean and standard deviation values of inhibitory zones were calculated using Microsoft Excel version 2010 .

\section{RESULTS AND DISCUSSION}

\subsection{Antibacterial activity of crude methanol extracts}

The screening assay of nine crude extracts against three common fish antibacterial pathogens were performed by agar disc diffusion method and the result was summarized in Table 2. There were no inhibitory zone of negative controls (DMSO) while the positive controls including Doxycycline, Florfenicol and Ampicillin showed strong antibacterial activity against $A$. hydrophila $(20 \pm 0.58$ $\mathrm{mm})$, E. ictaluri $(48.67 \pm 2.08 \mathrm{~mm})$ and S. agalactiae $(31.7 \pm 0.83 \mathrm{~mm})$, respectively. The diameters of inhibitory zones for the tested plant extracts were varied, ranging from 9.2 to $35 \mathrm{~mm}$. Most of the plant extracts showed the inhibitory activity against at least one tested bacterium. Among these extracts, Cleome chelidonii (Celandine spider flower), Combretum quadrangulare (bushwillows) and Premna corymbosa (headache tree) revealed a broad spectrum of inhibitory effect, although $C$. chelidonii extract showed a moderate activity against all tested bacteria. Additionally, the strongest antibacterial activity against $E$. ictaluri and $S$. agalactiae was demonstrated by the extract of $P$. corymbosa with the mean of inhibitory zone being $32.2 \pm 2.9 \mathrm{~mm}$ and $18.2 \pm 1.79 \mathrm{~mm}$, respectively. Limited information existed on the antibacterial activity against 3 tested bacteria of $P$. corymbosa and $C$. chelidonii extracts. However, their inhibitory effect against other bacteria was documented in literature (Immaculate \& Rani, 2015; Rahman et al., 2016). Sridhar et al. (2014) revealed the inhibitory activity of $C$. chelidonii methanol extract against both Gram-positive and Gram-negative bacteria including Bacillus subtilis, Staphylococcus aureus, Escherichia coli and Pseudomonas aeruginosa. The leaves extract of $P$. corymbosa was found to contain some bioactive compounds as alkaloids, tannins, flavonoids and glycosides with refer to antibacterial activity (Uppin \& Naik, 2017). Likewise, most isolated chemical constituents from $C$. quadrangulare belonging to the class of triterpenoids and flavonoids (Roy et al., 2014). Furthermore, the antibacterial activity of $C$. quadrangulare extract in this study is correlation with Trieu Thi Thanh Hang et al. (2018) who reported high antibacterial potential against $A$. hydrophila and E. ictaluri. 

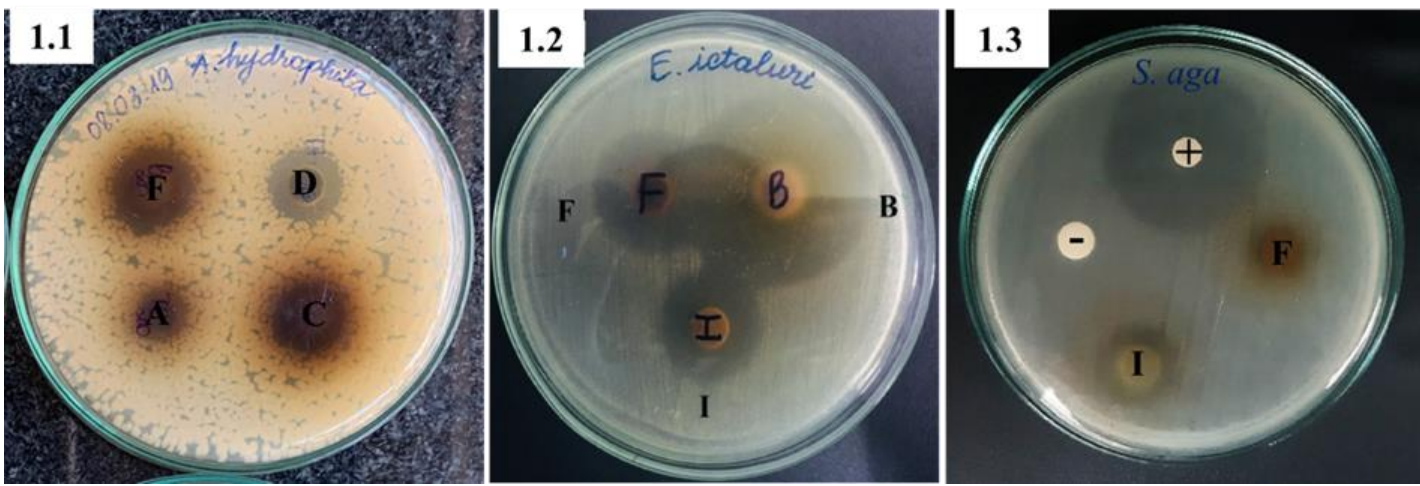

Figure 1. Antibacterial activity of crude methanol extracts against aquatic pathogenic bacteria

(1.1) A. hydrophila, (1.2) E. ictaluri, (1.3) S. agalactiae, (A) A. indica, (B) P. corymbosa, (C) C. quadrangulare, (D) C. scolymus, (F) K. pinnata, (I) C. trifolia, (+) Positive control, (-) Negative control

Among the tested bacteria, E. ictaluri was found to be the most sensitive to all tested plant extracts (Table 2), in which $P$. corymbosa, $C$. quadrangulare and Kalanchoe pinnata extracts showed strong inhibition, while the extracts of $C$. trifolia (fox grape), W. chinensis (Chinese wedelia), Azadirachta indica (neem), Xanthium strumarium (cocklebur), C. chelidonii (Celandine spider flower) and Cynara scolymus (artichoke) all showed a moderate activity (11-14 mm of inhibitory zone). As opposed to $E$. ictaluri, A. hydrophila was the most resistant bacterium, with 5/9 plant extracts including $A$. indica, $C$. trifolia, $W$. chinensis, $X$. strumarium and $C$. scolymus showed no inhibition or inhibition at weak level. The other extracts showed inhibitory effect at intermediate level with the largest zone of inhibition was recorded for $C$. trifolia extract $(15.5 \pm 0.61 \mathrm{~mm})$. Previous study also revealed the sensitivity of these two bacteria to various plant extracts (Huynh Kim Dieu, 2010), in which E. ictaluri and A. hydrophila were sensitive to $28 / 30$ and $15 / 30$ plant extracts, respectively. The results of present study were in contrast to those of Dao et al. (2020) who reported the ethanol extracts of $C$. trifolia, A. indica and $W$. chinensis were inactive to E. ictaluri. However, the three mentioned plant extracts did not exhibit inhibitory effect to $A$. hydrophila which was in agreement to the observation of Dao et al. (2020). Variations in the inhibitory effect of plant extracts against tested bacteria might be because of the differences in the plant part used, the age of plants and the local environmental conditions that affected the potency of plants (Ref). Furthermore, the extraction method and also solvent used could affect the amount of extracted bioactive compounds (Eloff, 1998; Azwanida, 2015).

Table 2. Antibacterial activity of crude methanol extracts

\begin{tabular}{clrrr}
\hline \multirow{2}{*}{ No. } & \multirow{2}{*}{ Plant extracts } & \multicolumn{3}{c}{ Zone of inhibition $(\mathbf{m m} \pm$ SD) } \\
\cline { 2 - 5 } & & A. hydrophila & E. ictaluri & S. agalactiae \\
\hline 1 & Azadirachta indica & 0 & $13.20 \pm 1.30$ & $10.60 \pm 1.81$ \\
2 & Cayratia trifolia & 0 & $13.90 \pm 1.58$ & $10.50 \pm 1.10$ \\
3 & Cleome chelidonii & $12.00 \pm 0.00$ & $12.66 \pm 1.53$ & $12.00 \pm 1.00$ \\
4 & Combretum quadrangulare & $13.67 \pm 0.58$ & $23.00 \pm 1.00$ & $16.67 \pm 0.58$ \\
5 & Cynara scolymus & $10.00 \pm 0.00$ & $11.30 \pm 0.58$ & $10.00 \pm 1.73$ \\
6 & Kalanchoe pinnata & $14.00 \pm 2.65$ & $19.66 \pm 0.58$ & 0 \\
7 & Premna corymbosa & $13.30 \pm 1.60$ & $32.20 \pm 2.90$ & $18.20 \pm 1.79$ \\
8 & Wedelia chinensis (Osbeck) Merr & 0 & $13.66 \pm 0.58$ & $19.70 \pm 1.53$ \\
9 & Xanthium strumarium & $9.20 \pm 1.30$ & $12.80 \pm 2.60$ & $12.20 \pm 1.09$ \\
10 & Doxycycline (30 $\mu$ g per disc) & $20.00 \pm 0.58$ & - & - \\
11 & Florfenicol & - & $48.67 \pm 2.08$ & - \\
12 & Ampicillin $(10 \mu \mathrm{y}$ per disc) & - & - & $31.70 \pm 0.83$ \\
13 & DMSO & 0 & 0 & 0 \\
\hline
\end{tabular}

Notes: (-) means not be tested.

Susceptible (S) $\geq 15 \mathrm{~mm}$, Intermediate resistant (I) $11-14 \mathrm{~mm}$ and Resistant $(R) \leq 10 \mathrm{~mm}$ (Okoth et al., 2013) 
According to previous antibacterial assay for screening purpose, the plant extracts were generally more effective to Gram-positive than Gram-negative bacteria (Dahiya \& Purkayastha, 2012), due to the cell wall structure complexity in Gram-negative bacteria (Silhavy et al., 2010). In this study, S. agalactiae was sensitive to almost tested plant extracts, except $K$. pinnata which showed no inhibition. Although no information on the antibacterial potential of $K$. pinnata against $S$. agalactiae, previous study demonstrated that various solvent extract of $K$. pinnata did not revealed any inhibitory effect against various bacteira such as B. subtilis, B. cereus, Staphylococcus epidermidis, and E. coli (Kamal et al., 2014). However, Castro et al. (2008) found that $S$. agalactiae was the most resistant bacteria when screened 46 methanol plant extracts against 3 fish pathogenic bacteria including A. hydrophila, F. columnare and $S$. agalactiae. Only 5 methanol plant extracts including Calyptranthes clusiifolia (Miq.), Croton floribundus, Heisteria silvianii, Merremia tomentosa, Zanthoxylum riedelianum Engl. exhibited the inhibitory effect to $S$. agalactiae (Castro et al., 2008).

\subsection{Antibacterial activity of solvent plant extracts}

$P$. corymbosa was selected for solvent extraction due to its strong and broad-spectrum antibacterial activity (Table 3 ). The result showed that crude methanol and methanol-water extract of P. corymbosa exhibited higher antibacterial activity than hexane and ethyl acetate extract. The crude methanol and methanol-water extract revealed strong inhibitory against all tested bacteria, while hexane and ethyl acetate extract was ineffective against $A$. hydrophila and $S$. agalactiae. However, the results showed an intermediate inhibition against $E$. ictaluri, with the diameters of the zone of inhibition being $10.8 \pm 1.5$ and $15.8 \pm 1.5 \mathrm{~mm}$ for hexane and ethyl acetate extract, respectively. Extraction is the important process because it is necessary to extract the desired bioactive compounds from the plant materials (Abdullahi R. \& Haque, 2020). The composition of bioactive compounds of the resulting extract is affected by various factors including extraction time, temperature, solvents extraction method and solvent type. The objective of extraction process is to maximize the amount of target compounds and to obtain the highest biological activity of these extracts.

Table 3. Antibacterial activity of $P$. corymbosa solvent extracts

\begin{tabular}{llrrr}
\hline \multirow{2}{*}{ Plant extracts } & \multirow{2}{*}{ Solvent fraction } & \multicolumn{3}{c}{ Zone of inhibition (mm) } \\
\cline { 3 - 5 } Premna corymbosa & Methanol & $13.3 \pm 1.5$ & $32.2 \pm 2.9$ & S. agalactiae \\
\hline & Methanol-Water & $14.3 \pm 0.7$ & $35.0 \pm 1.6$ & $18.2 \pm 1.8$ \\
& Hexane & 0 & $10.8 \pm 1.5$ & 0 \\
& Ethyl acetate & 0 & $15.8 \pm 1.5$ & 0 \\
\hline
\end{tabular}

\subsection{Minimum inhibitory concentration (MIC)} of plant extracts

The MIC value of each plant extract was in agreement with its zone of inhibition diameter in the case of E. ictaluri. For S. agalactiae, it was slightly on the contrary with the preliminary zone of inhibition which means some extracts having larger inhibitory zone but their MIC value was equal. As indicated in Table 4, the maximum MIC of $3.125 \mathrm{mg} / \mathrm{mL}$ against S. agalactiae was recorded in methanol extract of $C$. quadrangulare, $W$. chinensis and methanol-water extract of $P$. corymbosa. However, the methanol- water extract of $P$. corymbosa showed the minimum MIC of $0.39 \mathrm{mg} / \mathrm{mL}$ against $E$. ictaluri. Rajendran $\&$ Basha (2010) documented the MIC values of various solvent fractions (hexance, chloroform, ethyl acetate and ethanol) of $P$. corymbosa against $S$. $a u$ reus, E. coli, Pseudomonas aeuroginosa, Salmonella typhi, S. typhi typhi A, S. typhi B, Vibrio chlorea, Entero cocci, ranging from 33 to $133 \mu \mathrm{g} / \mathrm{mL}$, which was much lower than the MIC found in current study. The differences in bacterial strains and solvents used in the research could be explained in this case. 
Table 4. The MIC of plant extracts against respected bacteria

\begin{tabular}{lllr}
\hline Plants & Extract & Bacteria & MIC $(\mathbf{m g} / \mathbf{m L})$ \\
\hline $\begin{array}{l}\text { Combretum } \\
\text { quadrangulare }\end{array}$ & \multirow{2}{*}{ Methanol } & E. ictaluri & 1.56 \\
\hline Kalanchoe pinnata & Methanol & S. agalactiae & 3.125 \\
\hline \multirow{3}{*}{ Premna corymbosa } & \multirow{2}{*}{ Methanol } & E. ictaluri & 0.78 \\
& & S. ictaluri & 1.56 \\
& \multirow{2}{*}{ Methanol-Water } & E. ictaluariae & 1.56 \\
& & S. agalactiae & 0.39 \\
Wedelia chinensis & Methanol & S. agalactiae & 3.125 \\
\hline Although & & 3.125 \\
\hline
\end{tabular}

Although future study of in vivo antimicrobial activity and the phytochemical analysis of solvent fractions are required, our study confirmed the antibacterial activity against several aquatic pathogens was demonstrated by various plant extract materials, that can be considered as an alternative to synthetic antibiotics currently used in aquaculture practice.

\section{CONCLUSION}

The present study indicates that $P$. corymbosa and C. quadrangulare methanol extracts possess a significant strong and broad-spectrum of antimicrobial activity against the three bacterial pathogens such as E. ictaluri, A. hydrophila and S. agalactiae. It is assumed that these plants can be potentially used in combating fish bacterial diseases.

\section{ACKNOWLEDGMENT}

This study is funded in part by the Can Tho University Improvement Project VN14-P6, supported by a Japanese ODA loan.

\section{REFERENCES}

Abdullahi R., A., \& Haque, M. (2020). Preparation of the medicinal plants: Basic extraction and fractionation procedures for experimental purposes. Journal of Pharmacy and BioAllied Sciences, 12(1), 1-10. https://doi.org/10.4103/jpbs.JPBS

AftabUddin, S., Siddique, M. A. M., Romkey, S. S., \& William L. Shelton. (2017). Antibacterial function of herbal extracts on growth, survival and immunoprotection in the black tiger shrimp Penaeus monodon. Fish and Shellfish Immunology, 65, 5258. https://doi.org/10.1016/j.fsi.2017.03.050

Azwanida NN. (2015). A Review on the extraction methods use in medicinal plants, principle, strength and limitation. Medicinal \& Aromatic Plants, 04(03), 3-8. https://doi.org/10.4172/2167-0412.1000196

Bulfon, C., Volpatti, D., \& Galeotti, M. (2015). Current research on the use of plant-derived products in farmed fish. Aquaculture Research, 46(3), 513-551. https://doi.org/10.1111/are.12238

Castro, S. B. R., Leal, C. A. G., Freire, F. R., Carvalho, D. A., Oliveira, D. F., \& Figueiredo, H. C. P. (2008).
Antibacterial activity of plant extracts from Brazil against fish pathogenic bacteria. Brazilian Journal of Microbiology, 39(4), 756-760.

https://doi.org/10.1590/S1517-83822008000400030

Dahiya, P., \& Purkayastha, S. (2012). Phytochemical screening and antimicrobial activity of some medicinal plants against multi-drug resistant bacteria from clinical isolates. Indian Journal of Pharmaceutical Sciences, 74(5), 443-450. https://doi.org/10.4103/0250-474X.108420

Eloff, J. N. (1998). Which extractant should be used for the screening and isolation of antimicrobial components from plants? Journal of Ethnopharmacology, 60(1), 1-8. https://doi.org/10.1016/S0378-8741(97)00123-2

Evans, J. J., Klesius, P. H., Pasnik, D. J., \& Bohnsack, J. F. (2009). Human Streptococcus agalactiae isolate in Nile tilapia (Oreochromis niloticus). Emerging Infectious Diseases, 15(5), 774-776. https://doi.org/10.3201/eid1505.080222

Ha, T. D., Nguyen, V. K., \& Nguyen, T. H. (2011). Some characteristics of Streptococcus agalactiae, causative agent of Streptococcosis in Nile tilapia (Oreochromis niloticus) in Northern Vietnam. National Aquaculture Conference for Student and Yong Scientists, January, 348-356.

Huynh, K. D. (2010). Antibacterial activity of some medicinal plants in the Mekong Delta of Viet Nam against common fish pathogens. Can Tho University Journal of Science, 15b, 222-229.

Immaculate, A. R., \& Rani, U. V. (2015). A comparative study on in vitro antioxidant and antibacterial activities of methanol extract from the leaves of Stachytarpheta indica (L) Vahl and Premna corymbosa Rottl. International Journal of Current Pharmaceitical Research, 7(4).

Kamal, Y., Ch, B. A., Uzair, M., Irshad, N., Yaseen, M., \& Hussain, I. (2014). In vitro evaluation of antibacterial, antifungal and phytotoxicity of different extracts of leaves of Kalanchoe pinnata. Journal of Applied Pharmacy, 6(4), 446-450.

Najiah, M., Nadirah, M., Arief, Z., Zahrol, S., Tee, L. W., Ranzi, A. D., ... \& Aida, R. J. (2011). Antibacterial activity of Malaysian edible herbs extracts on 
fish pathogenic bacteria. Research Journal of Medicinal Plant, 5(6), 772-778.

Mishra, S. ., Das, R., \& Swain, P. (2018). Status of fish diseases in aquaculture and assessment of economic loss due to disease. In Contemporary trends in Fisheries and Aquaculture2 (pp. 183-199).

Mohammed, H. H., \& Arias, C. R. (2016). Protective efficacy of Nigella sativa seeds and oil against columnaris disease in fishes. Journal of Fish Diseases, 39(6), 693-703. https://doi.org/10.1111/jfd.12402

Ngo, V. H. (2015). The use of medicinal plants as immunostimulants in aquaculture: A review. Aquaculture, 446, 88-96. https://doi.org/10.1016/j.aquaculture.2015.03.014

Nguyen, L. A. D., Tran, M. P., Douny, C., QuetinLeclercq, J., Bui, T. B. H., Le, T. B., Truong, Q. N., Bui, T. B. H., Do, T. T. H., Nguyen, T. P., Kestemont, P., \& Scippo, M. L. (2020). Screening and comparative study of in vitro antioxidant and antimicrobial activities of ethanolic extracts of selected Vietnamese plants. International Journal of Food Properties, 23(1), 481-496. https://doi.org/10.1080/10942912.2020.1737541

Okoth, D. A., Chenia, H. Y., \& Koorbanally, N. A. (2013). Antibacterial and antioxidant activities of flavonoids from Lannea alata (Engl.) Engl. (Anacardiaceae). Phytochemistry Letters, 6(3), 476481. https://doi.org/10.1016/j.phytol.2013.06.003

Oonmetta-aree, J., Suzuki, T., Gasaluck, P., \& Eumkeb, G. (2006). Antimicrobial properties and action of galangal (Alpinia galanga Linn.) on Staphylococcus aureus. LWT - Food Science and Technology, 39(10), 1214-1220. https://doi.org/10.1016/j.lwt.2005.06.015

Quach, V. C. T., Tu, T. D., \& Dang, P. H. H. (2014). The current status antimicrobial resistance in Edwardsiella ictaluri and Aeromonas hydrophila cause disease on the striped catfish farmed in the Mekong Delta. Can Tho University Journal of Science, 2, 7-14.

Rahman, A., Sultana Shanta, Z., Rashid, M. A., Parvin, T., Afrin, S., Khodeza Khatun, M., \& Sattar, M. A. (2016). In vitro antibacterial properties of essential oil and organic extracts of Premna integrifolia Linn. Arabian Journal of Chemistry, 9, S475-S479. https://doi.org/10.1016/j.arabjc.2011.06.003

Rajendran, R., \& Basha, N. S. (2010). Antimicrobial activity of crude extracts and fractions of Premna serratifolia Lin. root. Medicinal Plants International Journal of Phytomedicines and Related Industries, 2(1), 33-38. https://doi.org/10.5958/j.0975-4261.2.1.004

Rico, A., Phu, T. M., Satapornvanit, K., Min, J., Shahabuddin, A. M., Henriksson, P. J. G., Murray, F. J., Little, D. C., Dalsgaard, A., \& Van den Brink, P. J. (2013). Use of veterinary medicines, feed additives and probiotics in four major internationally traded aquaculture species farmed in Asia. Aquaculture. https://doi.org/10.1016/j.aquaculture.2013.07.028

Roy, R., Raj, K. S., Jash, S. K., Sarkar, A., \& Gorai, D. (2014). Combretum quadrangulare (Combretaceae): Phytochemical constituents and biological activity. Indo American Journal of Pharmaceutical Research, 4(8), 3416-3427.

Silhavy, T. J., Kahne, D., \& Walker, S. (2010). The Bacterial Cell Envelope1 T. J. Silhavy, D. Kahne and S. Walker,. Cold Spring Harb Perspect Biol, 2, 1-16. https://www.ncbi.nlm.nih.gov/pmc/articles/PMC285 7177/pdf/cshperspect-PRK-a000414.pdf

Sreedharan, K., Philip, R., \& Singh, I. S. B. (2012). Virulence potential and antibiotic susceptibility pattern of motile aeromonads associated with freshwater ornamental fish culture systems: A possible threat to public health. Brazilian Journal of Microbiology, 43(2), 754-765. https://doi.org/10.1590/S1517-83822012000200040

Sridhar, N., Surya Kiran, B. V. V. S., Tharaka Sasidhar, D., \& Kanthal, L. K. (2014). In vitro antimicrobial screening of methanolic extracts of Cleome chelidonii and Cleome gynandra. Bangladesh Journal of Pharmacology, 9(2), 161-166. https://doi.org/10.3329/bjp.v9i2.17759

Trieu, T. T. H., Nguyen, C. T., Cao, D. T., \& Le, T. T. V. (2018). Study on the antibacterial activity of extracts from sakae naa (Combretum quadrangulare) on diseased aquatic animals-bacteria under in vitro condition. Can Tho University, Journal of Science, 54(2), 151-157. https://doi.org/10.22144/ctu.jsi.2018.048

Tu, T. D., Haesebrouck, F., Nguyen, A. T., Sorgeloos, P., Baele, M., \& Decostere, A. (2008). Antimicrobial susceptibility pattern of Edwardsiella ictaluri isolates from natural outbreaks of bacillary necrosis of Pangasianodon hypophthalmus in Vietnam. Microbial Drug Resistance, 14(4), 311-316. https://doi.org/10.1089/mdr.2008.0848

Tu, T. D., Nguyen, T. N. N., Nguyen, Q. T., Nguyen, A. T., Shinn, A., \& Crumlish, M. (2008). Common diseases of Pangasius catfish farmed in Vietnam. Global Aquaculture Advocate, July 2008.

Turker, H., Yildirim, A. B., \& Karakaş, F. P. (2009). Sensitivity of bacteria isolated from fish to some medicinal plants. Turkish Journal of Fisheries and Aquatic Sciences, 9(2), 181-186. https://doi.org/10.4194/trjfas.2009.0209

Uppin, J. B., \& Naik, G. R. (2017). Evaluation of phytochemical and antimicrobial activity of Premna integrifolia leaf extract. European Journal of Biotechnology and Bioscience, 5(5), 17-19.

Zilberg, D., Tal, A., Froyman, N., Abutbul, S., Dudai, N., \& Golan-Goldhirsh, A. (2010). Dried leaves of Rosmarinus officinalis as a treatment for streptococcosis in tilapia. Journal of Fish Diseases, 33(4), 361-369. https://doi.org/10.1111/j.13652761.2009.01129.x 